\title{
MICROBIOLOGICAL ASSESSMENT OF FRESH EXPRESSED BREAST MILK ON ROOM TEMPERATURE AT DR. SOETOMO HOSPITAL NEONATAL UNIT
}

\author{
Nur Aisyah Widjaja, Kartika Hardiyani, Meta Herdiana Hanindita, Roedi Irawan \\ Division of Nutrition and Metabolic Disease, Departement of Pediatric, Faculty of Medicine, Universitas Airlangga, \\ Surabaya, Indonesia
}

\section{ABSTRACT}

\begin{abstract}
Storing EBM at room temperature in several hours before consuming, frequently found in Indonesia. Based on Academy of Breastfeeding Medicine guidelines EBM can last for 6 to 8 hours in room temperature $\left(25^{\circ} \mathrm{C}\right.$ or $\left.77^{\circ} \mathrm{F}\right)$. However, currently there hasn't been study in tropical country especially Indonesia for the guidelines. This study aimed to assess microbiological quality of EBM on room temperature, including bacterial growth and major bacterial found on EBM for health care and society recommendations. An observational study of 30 expressed breast milk samples provided by 30 healthy women with term baby below 6 month old. The samples were kept sterile and laid at plates for 0 hours, 2 hours, 4 hours and 6 hours in room temperature $\left(26^{\circ}-32^{\circ}\right.$ C) and used drop plate technique on several culture media. Data was analyzed by Chi-square and paired sample T-test. Thirty of unheated fresh EBM from 30 lactating mothers were stored at room temperature, examined for the degree of bacterial contamination at 0 hour, 2 hours, 4 hours, and 6 hours. All the EBM samples were contaminated at 2 hour. Bacterial species identified was Coagulase-negative Staphylococcus (CNS), Escherichia coli, Klebsiella pneumoniae and Streptococcus faecalis, range of growth $10^{9}$ $c f u / m l-63 \times 10^{9} \mathrm{cfu} / \mathrm{mm} 3$ after 6 hour of storage. The EBM exposed at room temperature $\left(30-36^{\circ} \mathrm{C}\right)$ for more than two hour reduce the quality and do not recommended to be given to the infants.
\end{abstract}

Keywords: Expressed breast milk; room temperature; bacterial growth; human milk; breast milk

\section{ABSTRAK}

\begin{abstract}
Menyimpan EBM pada suhu kamar dalam beberapa jam sebelum dikonsumsi, sering ditemukan di Indonesia. Berdasarkan pedoman Academy of Breastfeeding Medicine, EBM dapat bertahan selama 6 hingga 8 jam dalam suhu kamar $\left(25^{\circ} \mathrm{C}\right.$ atau $\left.77^{\circ} \mathrm{F}\right) . \mathrm{Namun}$, saat ini belum ada studi di negara tropis terutama Indonesia untuk pedoman. Penelitian ini bertujuan untuk menilai kualitas mikrobiologis EBM pada suhu kamar, termasuk pertumbuhan bakteri dan bakteri utama yang ditemukan pada EBM untuk perawatan kesehatan dan rekomendasi masyarakat. Sebuah penelitian observasional terhadap 30 sampel ASI yang diekspresikan diberikan oleh 30 wanita sehat dengan bayi cukup bulan di bawah 6 bulan. Sampel disimpan steril dan diletakkan di piring selama 0 jam, 2 jam, 4 jam dan 6 jam dalam suhu kamar $\left(26^{\circ}-32^{\circ} \mathrm{C}\right)$ dan menggunakan teknik drop plate pada beberapa media kultur. Data dianalisis dengan uji Chi-square dan paired sample T-test. Tiga puluh EBM segar yang tidak dipanaskan dari 30 ibu menyusui disimpan pada suhu kamar, diperiksa tingkat kontaminasi bakteri pada 0 jam, 2 jam, 4 jam, dan 6 jam. Semua sampel EBM terkontaminasi pada 2 jam. Spesies bakteri yang diidentifikasi adalah Coagulase-negative Staphylococcus (CNS), Escherichia coli, Klebsiella pneumoniae dan Streptococcus faecalis, kisaran pertumbuhan $10^{9} \mathrm{cfu} / \mathrm{ml}-63 \times 10^{9} \mathrm{cfu} / \mathrm{mm} 3$ setelah penyimpanan 6 jam. EBM yang terpapar pada suhu kamar $\left(30-36^{\circ} \mathrm{C}\right)$ selama lebih dari dua jam mengurangi kualitas dan tidak direkomendasikan untuk diberikan kepada bayi.
\end{abstract}

Kata kunci: ASI; suhu kamar; pertumbuhan bakteri; susu manusia; ASI

Correspondence: Nur Aisyah Widjaja, Villa kalijudan Indah N-33, Surabaya 60114, Indonesia. Phone: +62 812-3073379. E-mail: nuril08@yahoo.com

pISSN:2355-8393 • eISSN: 2599-056x • doi: http://dx.doi.org/10.20473/fmi.v55i1.12552

- Fol Med Indones. 2019;55:30-36• Received 23 Feb $2018 \bullet$ Accepted 21 Jun 2018

- Open access under CC-BY-NC-SA license • Available at https://e-journal.unair.ac.id/FMI/

\section{INTRODUCTION}

Breast milk plays a protective roles against a wide range of infectious and other diseases, especially in developing countries, because of anti-microbial and other immunological substances such as imunoglobulins, lysozymes, lactoperoxidase, lactoferrin, complement components and active leucocytes (Lorico et al 2012). 
Mothers are not always disposed to breastfeed their babies adequately because of several reasons such as working or schooling, consequences on poor breastfeeding on their babies. This situation forces mothers to expressed breast milk (EBM) that has been advocated as an effective way of encouraging and maintaining lactation when the mother is separated from the baby for a while.

Milk is a good medium for the growth of many microorganisms, thereby making it a possible means of transmission of microbial infections when it is not properly collected, processed and stored (Obiajuru et al 2017). Bacterial growth at suboptimal storage temperatures (temperature $15-38^{\circ} \mathrm{C}$ ) is often found to increase in developing countries as well as in workplace situations in industrialized countries.

Like living tissues and other fluids, breast milk is very sensitive to temperature changes, and some nutrient content and bioactive content may be affected by storage (Bransburg-Zabary et al 2015). Storing EBM in room temperature in several hours before consuming frequently found in Indonesia. Academy of Breastfeeding Medicine guidelines states that EBM can last for 6 to 8 hours in room temperature $\left(25^{\circ} \mathrm{C}\right.$ or $\left.77^{\circ} \mathrm{F}\right)$, but currently there hasn't been study of microbiological assessment of EBM on room temperature in tropical country, especially Indonesia for the guidelines.

This study was undertaken to determine microbiological quality of EBM on room temperature, including bacterial growth and major bacterial found on EBM for health care and society recommendations.

\section{MATERIALS AND METHODS}

This study was conducted among a group of healthy lactating woman at Dr. Soetomo Hospital Surabaya Indonesia. Samples of EBM were collected from 30 lactating women who willingly donated their EBM. Inclusion criteria for participating in this study was that the mothers must have lactating for less than 6 month, term birth, and have not been placed on antibiotics for up to six weeks before sample collection. The sample collected using electric breast pump swing model on Maret-May 2017. A structured questionnaire was distributed to the subjects to elicit information on their practices concerning expressed and stored breasr milk.

Five ml of EBM was taken using a sterile syringe and transferred to a sterile breast milk plastic bag, and brought to the microbiology section and considered to be a 0 hour. The samples were stored at open plates for 2 hours, 4 hours and 6 hours in room temperature $\left(30^{\circ}\right.$ - $32^{\circ} \mathrm{C}$ ) and used drop plate technique on several culture media. The samples were analyzed for types of bacteria and bacterial load at $0,2,4$, and 6 hour with drop plate technique using agar medium.

Culture media used this study include Nutrient Agar, Blood Agar and MacConkey`s Agar, sterilized using autoclave at $121^{\circ} \mathrm{C}$ for 15 minutes. $1 \mathrm{ml}$ of each breast milk sample was serially diluted (10-1, 10-2, 10-3 and 10-4). The dilution was properly shaken and a dilution of (10-2) was inoculated on sterile media for colony counting using Nutrient agar (NA). Blood agar was used to identify Gram-positive and Gram-negative bacteria. Mac Conkey agar was used to differentiate between lactos and non-lactose fermenting organisms. Cultures were grown at $35-37^{\circ} \mathrm{C}$ for 24 hours as per laboratory protocol. After 24 hours, a sterile wire loop was used to pick isolates from the plate and was streaked on freshly prepared blood agar and MacConkey agar and then incubated for 4 hours at $37^{\circ} \mathrm{C}$ in order to get pure culture. After incubation all colonies form a section of incubated plates were examined microscopically for Gram reaction, cell morphology and motility. Biochemical analysis included catalase, oxidase and urease activities as well as indole tes and patterns of sugar utilization. The isolates were identified based on the results obtained from biochemical characterization and microscopic examinations. Data of bacterial counts was analyzed by Chi-square and paired T-test using SPSS version 16.0. The value of $\mathrm{p}<0.05$ was considered as statistically significant.

\section{RESULTS}

Table 1 shows the socio-demographic characteristics of the lactating mother $(n=30)$. More than half subjects $(56.67 \%)$ of the subjects were between age range of 20 6 years. Half mother had basic education suggested by Indonesian goverment (elementary until senior high shool/ 9 years of education), while half of the rest got education only elementary and junior high school. $66.67 \%$ of the lactating mother were full ttime housewives, the rest were working mother (goverment and private employer). More than half the income (60\%) with income between 1-5 million rupiah, there is (30\%) with income $<1$ million rupiah and the rest with income $>5$ million rupiah.

Practices of the mother on storage of EBM revealed that most mother store it on refrigerator $(66.67 \%)$, while the rest stored it at room temperature $(33.33 \%)$. $70 \%$ of the mother using bottle feeding for EBM to feed their babies, and $30 \%$ using spoon and cup to feed their baby by EBM. 
Table 1. Socio-demographic characteristics of lactating women $(n=30)$

\begin{tabular}{|c|c|c|}
\hline Maternal data & Subjects & Percentage $\%$ \\
\hline \multicolumn{3}{|l|}{ Age } \\
\hline$<20$ years & 4 & 13.33 \\
\hline 20-30 years & 17 & 56.67 \\
\hline$>30$ years & 9 & 30 \\
\hline \multicolumn{3}{|l|}{ Weight (kg) } \\
\hline$<50 \mathrm{~kg}$ & 2 & 6,67 \\
\hline $50-70 \mathrm{~kg}$ & 19 & 63.33 \\
\hline$>70 \mathrm{~kg}$ & 9 & 30 \\
\hline \multicolumn{3}{|l|}{ Baby Birth Weight } \\
\hline$<2500 \mathrm{~g}$ & 19 & 63.33 \\
\hline$>2500 \mathrm{~g}$ & 11 & 36.67 \\
\hline House wife & 20 & 66.67 \\
\hline Working & 10 & 33.33 \\
\hline \multicolumn{3}{|l|}{ Educational Status } \\
\hline Elementary school & 9 & 30 \\
\hline Junior High school & 6 & 20 \\
\hline Senior High School & 8 & 26.67 \\
\hline College & 7 & 23.33 \\
\hline \multicolumn{3}{|l|}{ Income } \\
\hline$<1,000,000$ (Rupiahs) & 9 & 30 \\
\hline $1,000,000-5,000,0000$ (Rupiahs) & 18 & 60 \\
\hline$>5,000,0000$ (Rupiahs) & 3 & 10 \\
\hline \multicolumn{3}{|l|}{ Stored EBM } \\
\hline Refrigerator (Freezer) & 20 & 66.67 \\
\hline Room temperature & 10 & 33.33 \\
\hline \multicolumn{3}{|l|}{ Feeding Methods } \\
\hline Bottle & 21 & 70 \\
\hline Cup and spoon & 9 & 30 \\
\hline \multicolumn{3}{|l|}{ Frequency of expressed breast milk } \\
\hline Routine & 5 & 16.67 \\
\hline Not routine & 12 & 40 \\
\hline Never & 13 & 43.33 \\
\hline
\end{tabular}

Table 2. Percentage of positive and negative samples of EBM found in 0, 2, 4 and 6 hour after exposed at room temperature

\begin{tabular}{|c|c|c|c|c|c|c|c|c|}
\hline Microorganism & 0 hour & $\%$ & 2 hour & $\%$ & 4 hour & $\%$ & 6 hour & $\%$ \\
\hline $\begin{array}{l}\text { Positive } \\
\text { contaminated }\end{array}$ & 2 & $0.67 \%$ & 16 & $76.67 \%$ & 23 & $83.33 \%$ & 30 & $100 \%$ \\
\hline $\begin{array}{l}\text { Negative } \\
\text { contaminated }\end{array}$ & 28 & $93.33 \%$ & 14 & $23.33 \%$ & 7 & $16.67 \%$ & - & - \\
\hline Total & 30 & $100 \%$ & 30 & $100 \%$ & 30 & $100 \%$ & 30 & $100 \%$ \\
\hline
\end{tabular}

Bacteriological test of the samples (Table 2) showed that at 0 hour there are 2 samples are positive contaminated by bacteria. The amount of contaminated samples increase by the time at 2 hour $\left(2 \times 10^{2}-1.2 \times 10^{5}\right.$; averange $\left.1,09 \times 10^{4} \mathrm{cfu} / \mathrm{ml}\right)$ and 4 hour $\left(2 \times 10^{6-} 1.4 \times 10^{8}\right.$; averange value $\left.3.2 \times 10^{8} \mathrm{cfu} / \mathrm{ml}\right)$. At 6 hour all samples are contaminated $\left(10^{8}-60 \times 10^{9}\right.$ averange value $26.2 \times 10^{9}$ $\mathrm{cfu} / \mathrm{ml})$.

At 2 hour of exposure, 16 samples are positive contaminated by the bacteria, but only four samples (of contaminated samples) had bacterial count $>10^{4} \mathrm{cfu} / \mathrm{ml}$ (see Table 3). 
Table 3. Laboratory assessment of bacteria found in EBM

\begin{tabular}{|c|c|c|c|c|c|c|c|c|c|c|c|}
\hline No & $\begin{array}{c}0 \\
\text { hour }\end{array}$ & $\begin{array}{c}2 \\
\text { hour }\end{array}$ & $\begin{array}{l}\text { Bacteria } \\
\text { counts } \\
\text { cfu/ml }\end{array}$ & $\begin{array}{c}4 \\
\text { hour }\end{array}$ & $\begin{array}{l}\text { Bacteria } \\
\text { counts } \\
\text { cfu/ml }\end{array}$ & $\begin{array}{c}6 \\
\text { hour }\end{array}$ & $\begin{array}{l}\text { Bacteria } \\
\text { counts } \\
\text { cfu/ml }\end{array}$ & $\begin{array}{l}\text { Coagulase- } \\
\text { negative } \\
\text { Staphylococcus }\end{array}$ & E. coli & $\begin{array}{c}\text { Klebsiella } \\
\text { pneumonia }\end{array}$ & $\begin{array}{c}\text { Streptococcus } \\
\text { faecalis }\end{array}$ \\
\hline 1 & - & + & $2 \times 10^{2}$ & + & $8 \times 10^{6}$ & + & $38 \times 10^{9}$ & + & - & + & - \\
\hline 2 & - & - & - & + & $12 \times 10^{6}$ & + & $23 \times 10^{9}$ & + & - & + & - \\
\hline 3 & - & + & $2 \times 10^{3}$ & + & $14 \times 10^{7}$ & + & $22 \times 10^{9}$ & + & + & - & - \\
\hline 4 & + & + & $9 \times 10^{3}$ & + & $19 \times 10^{6}$ & + & $4.5 \times 10^{9}$ & + & + & - & - \\
\hline 5 & - & + & $7 \times 10^{2}$ & + & $21 \times 10^{5}$ & + & $2.9 \times 10^{9}$ & + & - & + & - \\
\hline 6 & - & - & - & - & - & + & $40 \times 10^{9}$ & + & - & + & - \\
\hline 7 & - & + & $2 \times 10^{3}$ & + & $7 \times 10^{6}$ & + & $1.7 \times 10^{9}$ & + & + & - & - \\
\hline 8 & - & + & $3 \times 10^{4}$ & + & $11 \times 10^{7}$ & + & $25 \times 10^{9}$ & + & + & - & - \\
\hline 9 & - & - & - & - & - & + & $31 \times 10^{9}$ & + & + & - & + \\
\hline 10 & + & + & $12 \times 10^{4}$ & + & $24 \times 10^{6}$ & + & $60 \times 10^{9}$ & + & - & - & + \\
\hline 11 & - & + & $11 \times 10^{4}$ & + & $23 \times 10^{6}$ & + & $58 \times 10^{9}$ & + & - & + & - \\
\hline 12 & - & - & - & - & - & + & $0.8 \times 10^{9}$ & + & - & + & - \\
\hline 13 & - & + & $3 \times 10^{3}$ & + & $13 \times 10^{5}$ & + & $28 \times 10^{9}$ & + & + & + & - \\
\hline 14 & - & + & $2 \times 10^{2}$ & + & $11 \times 10^{5}$ & + & $0.1 \times 10^{9}$ & + & + & - & - \\
\hline 15 & - & - & - & - & - & + & $37 \times 10^{8}$ & + & - & - & - \\
\hline 16 & - & + & $5 \times 10^{2}$ & + & $11 \times 10^{6}$ & + & $25 \times 10^{9}$ & + & - & + & - \\
\hline 17 & - & + & $4 \times 10^{4}$ & + & $14 \times 10^{6}$ & + & $31 \times 10^{9}$ & + & - & + & - \\
\hline 18 & - & - & - & + & $13 \times 10^{5}$ & + & $2.5 \times 10^{9}$ & + & - & + & - \\
\hline 19 & - & - & - & + & $20 \times 10^{6}$ & + & $3.1 \times 10^{9}$ & + & - & - & + \\
\hline 20 & - & - & - & + & $15 \times 10^{5}$ & + & $34 \times 10^{9}$ & + & - & + & + \\
\hline 21 & - & - & - & - & - & + & $29 \times 10^{9}$ & + & - & + & - \\
\hline 22 & - & - & - & + & $16 \times 10^{6}$ & + & $43 \times 10^{9}$ & + & - & + & - \\
\hline 23 & - & - & - & - & - & + & $37 \times 10^{9}$ & + & - & + & - \\
\hline 24 & - & - & - & + & $18 \times 10^{5}$ & + & $27 \times 10^{9}$ & + & - & + & - \\
\hline 25 & - & + & $4 \times 10^{3}$ & + & $11 \times 10^{5}$ & + & $31 \times 10^{9}$ & + & - & + & - \\
\hline 26 & - & + & $2 \times 10^{3}$ & + & $7 \times 10^{6}$ & + & $0.2 \times 10^{9}$ & + & - & - & - \\
\hline 27 & - & - & - & + & $24 \times 10^{6}$ & + & $51 \times 10^{9}$ & + & - & - & + \\
\hline 28 & - & - & - & - & - & + & $37 \times 10^{9}$ & + & - & - & - \\
\hline 29 & - & + & $6 \times 10^{3}$ & + & $32 \times 10^{7}$ & + & $63 \times 10^{9}$ & + & - & - & - \\
\hline 30 & - & + & $3 \times 10^{2}$ & + & $9 \times 10^{5}$ & + & $1 \times 10^{8}$ & + & - & - & - \\
\hline Mean & & & $2.06 \times 10^{4}$ & & $3.2 \times 10^{8}$ & & $2.6 \times 10^{10}$ & & & & \\
\hline
\end{tabular}

Table 4. Distribution of microbial analysis of the samples

\begin{tabular}{clcc}
\hline No & \multicolumn{1}{c}{ Bacteria Species } & Total samples & $\%$ \\
\hline 1 & Coagulase-negative Staphylococcus & 30 & $62.50 \%$ \\
2 & Klebsiella pneumoniae & 11 & $22.92 \%$ \\
3 & Escherichia coli & 4 & $3.33 \%$ \\
4 & Streptococcus faecalis & 3 & $6.25 \%$ \\
\hline
\end{tabular}

Bacterial identification of the samples as presented in Table 4 showed that the predominant microorganisms isolated were coagulase-negative Staphylococcus (62.50 $\%)$, Escherichia coli (13.33\%), Klebsiella pneumoniae $(36.67 \%)$ and Streptococcus faecalis (10\%). The most common species of contaminant is coagulase-negative Staphylococcus, presence in all samples.

Coagulase-negative Staphylococcus is a group Gram positive, catalase positive and grow well in blood agar, representing the majority of normal skin flora. Escherichia coli is Gram negative, indole positive and coagulase negative, while Streptococcus faecalis is Gram positive, motile, and coagulase negative, catalase negative and ferments glucose. Klebsiella pneumoniae is Gram negative, motile, and coagulase negative.

Statistical analysis showed that there were strong correlation between 2 hours storing with 4 hours storing $(\mathrm{p}=0.001)$; total colony at 4 hour and total colony at 6 hour ( $\mathrm{p}=0.047)$; and 2 hour and 6 hour $(\mathrm{p}=0.02)$. There were also significant difference between bacterial colony and the duration itself $(\mathrm{p}=0.026)$. 


\section{DISCUSSION}

There are several information about microbiological safe preparation of EBM considered acceptable: less than $10^{4} \mathrm{cfu} / \mathrm{ml}$ of mesophilic bacteria, with the total count of enterobacteria lower than $10 \mathrm{cfu} / \mathrm{ml}$ (Asquith \& Harrod 1979); and no presence of pathogenic bacteria such as Escherichia coli, Staphylococcus aureus, Streptococcus faecalis, Enterobacter sakazakii, (ßhemolytic) Streptococcus pyrogenes, species of Pseudomonas, Proteus and Salmonella (Serra et al 2013).

The findings achieve in the study showed that after 2 hours exposed at open room temperature, $76.67 \%$ of EBM samples have been contaminated (the colony count is $>10^{4} \mathrm{cfu} / \mathrm{ml}$ ) and the presence of several pathogens (Escherichia coli, Streptococcus faecalis and Klebsiella pneumoniae) suggested that the EBM samples are not safety to be given to the infants. The study conducted by Karimi et al reveal that $85 \%$ samples collecting from Neonatal Intensive Care Unit, Yazd Iran were infected by bacteria, and the dominant genus was Klebsiella (Karimi et al 2013).

Study has shown that the best method of storing expressed breast milk is in refrigerator at $4^{\circ} \mathrm{C}$ temperature, especially in hot climate (Marin et al 2009, Martinez-Costa et al 2007). Other studies (Tully 2000, Zinn 2000) have been carried out in optimum conditions of storage noted that EBM could last for up to 3-8 days in the refrigerator. Indonesia is a tropical country with two seasons all year (summer and rainy season) with extreme temperatures between the two seasons $\left(30-37^{\circ} \mathrm{C}\right.$ in summer and $27-28^{\circ} \mathrm{C}$ rainy).

Ighogboja et al (1996) state that many mothers will not give EBM because they think EBM is not safe given to babies after more than 8 hours of storage. Further study that EBM would very easily be contaminated with bacteria, toxic, and can become diluted and acid after storage. Research of the time difference in the length of storage can cause many changes the nutrient contents (Ighogboja et al 1996).

Freshly collected breast milk is rarely sterile and normally contains bacteria originated from the maternal skin and nipple duct micro-flora, but it also contain potential pathogens (Ogundele 2000). Gransden et al (1986) reported that the breast pump was an important sources of bacterial contamination of EBM. The study conducted by Boo et al (2001) confirmed that manual expression (using hands) had lower risk of contamination than expressed breast milk using breast pump.
It is well known that differences in geographic locations and in the time and methods of milk collection affect the results of analysis of breast milk microbiota ( $\mathrm{Li}$ et al 2017). Fitzstevens et al (2017) suggested that two genera, Streptococcus and Staphylococcus, may be universally predominant in human milk, regardless of differences in geographic location or analytical methods.

There are four species isolated: Staphylococcus coagulase, Escherichia coli, Klebsiella pneumoniae and Streptococcus faecalis. Mense et al (2013) observed the bacterial contamination of mecanically extracted breast milk in 50 mother including species of Staphylococcus coagulase, Escherichia coli, Klebsiella pneumoniae and Streptococcus faecalis. The other species were Staphylococcus aureus, Alpha-hemolytic streptococci and dermal bacteria.

Coagulase-negative Staphylococcus (CNS) was a predomintants species, presents in all samples, because this species is a dominant organism in normal skin flora and most commonly isolated from blood cultures (Cunha et al 2004). Delgado et al (2009) proposed that disruption in the normal bacterial flora balance in breast milk may lead to CNS overgrowth and mastitis.

It is believed that about $8 \%$ of nosoclominal infections occuring in patients of neonatal intensive care units is caused by Klebsiella pneumoniae (KLP) (Donowitz et al 1981). Dorota et al's (2017) study observing newborns with recurrent infections found out that the source of infection was the contaminated breast milk with Klebsiella pneumoniae.

Escherichia coli presents in the samples indicated that contamination by coliform microorganisms may originate from the environment, means the low level of hygiene and sanitary practices (Serafini et al 2003). Among the enterobacterias, coliforms have been singled out as particularly important bacteriological control of HMBs, since their presence may indicate faecal contamination, even if it originates from an indirect sources (Serafini et al 2003). Other study found Escherichia coli in $8.5 \%$ of the 59 sample of breast milk (Szollosy et al 1974) and 2\% of 44 samples (Eidelman \& Szigagyi 1979).

Breast milk has high agglutinating titres to a variety of E. coli serotype (Gindrat et al 2000). Lorico et al (2012) observed the bacterial growth inhibiting activity of EBM on Eschericia coli, Klebsiella pneumoniae and Staphylococcus aureus and stated that breast milk exhibit bacteriostatic properties againts most pathogens except for Escherichia coli after being frozen for 24 hours. 
Table 5. Treatment of EBM depending on bacterial count, modified according to Henker (1987)

\begin{tabular}{|c|c|c|c|}
\hline Group & Bacterial count $(\mathrm{cfu} / \mathrm{ml})$ & Bacterial differentiation & Consequence \\
\hline I & $<1,000\left(10^{3}\right)$ & $\mathrm{n} / \mathrm{a}$ & No pasteurization \\
\hline II & $<10,000\left(10^{4}\right)$ & $\mathrm{n} / \mathrm{a}$ & $\begin{array}{l}\text { Pasteurization for baby weight }<1,500 \mathrm{~g} \text {; no } \\
\text { pasteurization for baby weight }>1,500 \mathrm{~g}\end{array}$ \\
\hline IIIIa & $<100,000\left(10^{5}\right)$ & $\begin{array}{l}<10,000 / \mathrm{ml} \text { potential } \\
\text { pathogenic bacteria }\end{array}$ & Pasteurization \\
\hline IIIb & $<100,000\left(10^{5}\right)$ & $\begin{array}{l}>10,000 / \mathrm{ml} \text { potential } \\
\text { pathogenic bacteria }\end{array}$ & Discarding \\
\hline IV & $>100,000\left(10^{5}\right)$ & $\mathrm{n} / \mathrm{a}$ & Discarding \\
\hline
\end{tabular}

It is recommended to reduce the amount of bacteria and pathogens in breast milk according to Henker (1987) (table 5) before giving the contaminated EBM to feed the infants.

\section{CONCLUSION}

Evaluation results that the EBM exposed at room temperature $\left(30-36^{\circ} \mathrm{C}\right)$ for more than two hour reduce the quality because bacterial counts $>10^{4} \mathrm{cfu} / \mathrm{ml}$ and the presence of pathogens E. coli, Streptococcus faecalis and Klebsiella pneumoniae were found.

\section{REFERENCES}

Asquith M and Harrod J (1979). Reduction of bacterial contamination in banked human milk. J Pediatr 95, 993-994

Boo N, Nordiah AJ, Alfizah H, Lim VKE (2001). Contamination of breast milk obtained by manual expression and breast pumps in mothers of very low birthweight infants. J Hosp Infect 49, 274-281

Bransburg-Zabary S, Virozub A, Mimouni A (2015). Human Milk Warming Temperatures Using a Simulation of Currently Available Storage and Warming Methods. PLoS ONE 10, 1-13

Cunha M, Sinzato L, Silveira Y (2004). Comparison of Methods for the Identification of Coagulasenegative Staphylococci. Mem Inst Oswaldo Cruz 99, 85588560

Delgado S, Arroyo R, Jiménez E, Marín ML, Del Campo R, Fernández L, Rodríguez JM (2009). Staphylococcus epidermidis strains isolated from breast milk of women suffering infectious mastitis: potential virulence traits and resistance to antibiotics. BMC Microbiol 9, 82-93

Donowitz LG, Marsik FJ, Fisher KA, Wenzel RP (1981). Contaminated breast milk: a source of Klebsiella bacteremia in a newborn intensive care unit. Rev Infect Dis 3,716-720
Dorota P, Chmielarczyk A, Katarzyna L, Piotr M, Jan L, Renata R, Jadwiga W (2017). Klebsiella pneumoniae in Breast Milk-A Cause of Sepsis in Neonate. Arch Med 9, 1

Eidelman A, Szilagyi G, (1979). Patterns of bacterial colonization of human milk. Obstet Gynecol 53, 550552.

Fitzstevens J, Smith KC, Hagadorn JI, Brownell EA (2017). Systematic Review of the Human Milk Microbiota. Nutr Clin Pract 32, 354-364

Gindrat J, Gothefors L, Hanson L, Winberg J. (1972). Antibodies in human milk against $\mathrm{E}$ coli of the serogroups most commonly found in neonatal infections. Acta Paediatr Scand 61, 587-590

Gransden WR, Webster M, French GL, Phillips I (1986). An outbreak of Serratia marcescens transmitted by contaminated breast pumps in a special care baby unit. J Hosp Infect 7, 149-154

Henker J (1987). Collection and preservation of breast milk. Monatsschr Kinderheilkd 35, 231-234

Ighogboja I, Odumodu C, Olarewaju R (1996). Breastfeeding pattern in Jos, Nigeria, before Baby Friendly Hospital Initiative. J Trop Pediatr 42, 178179.

Karimi M, Eslami Z, Lotfi MH, Nori S, Zandi H, Taghipour-Zahir S, Akhondzardaini R (2013). Bacterial contamination of expressed breast milk in neonatal intensive care unit. J Res Health Sci 13, 4347

Li S, Watanabe K, Hsu C, Chao S, Huang H, Chang C, Moore RJ (2017). Bacterial Composition and Diversity in Breast Milk Samples from Mothers Living in Taiwan and Mainland China. Front Microbiol 8, 965

Lorico JLL, Perez L, Makati O (2012). Effect of storage process on the bacterial growth-inhibiting activity of expressed human breast milk on common neonatal pathogens, Staphylococcus aureus, Escherichia coli and Klebsiella pneumoniae. PIDSP Journal 13, 2-7

Marin ML, Arroyo R, Jimenez E, Gomez A, Fernandez L, Rodriguez JM (2009). Cold Storage of Human 
Milk: Effect on Its Bacterial Composition. J Pediatr Gastroenterol Nutr 49, 343-348

Martinez-Costa C, Silvestre DM, Lopez MC, Plaza A, Miranda M, Guijarro R (2007). Effects of Refrigeration on the Bactericidal Activity of Human Milk: A Preliminary Study. J Pediatr Gastroenterol Nutr 45, 275-277

Mense L, Rößler S, Mense L (2013). Bacterial Contamination of Mechanically Extracted Breast Milk. Am J Perinatol 31, 293-298

Obiajuru IOC, Ikpeama CA, Ilo JCE (2017). Microbiological assessment and storage quality of expressed breast milk. IJMPD 1, 5-9

Ogundele M (2000). Techniques for storage of human breast milk: implications for anti-microbial functions and safety of stored milk. Eur J Pediatr 159,793-797
Serafini ÁB, André MCDPB, Rodrigues MAV, Kipnis A, Carvalho CO, Campos MRH, Jubé TFN (2003). Microbiological quality of human milk from a Brazilian milk bank. Rev Saude Publica 37, 775-779

Serra V, Teves S, López de Volder A (2013). Comparison the risk of microbiological contamination between samples of breast milk obtained at home and at a healthcare facility. Arch Argent Pediatr 111, 115119

Szollosy E, Marjai E, Lantos J (1974). Bacterial contamination and sparing heat treatment of mother's milk. Acta Microbiol Acad Sci Hungarian 21, 319-325

Tully M (2000). Recommendations for handling of mother's own milk. J Hum Lact 16,149-151

Zinn B (2000). Supporting the employed breast feeding mother. J Midwifery Womens Health 45, 216-226 